\title{
Effectiveness of nutrition centers in Ceará state, northeastern Brazil
}

\author{
Cristina Maria Gomes do Monte, ${ }^{1}$ Ann Ashworth, ${ }^{2}$ \\ Maria Lúcia Barreto Sá, ${ }^{3}$ and Regina Lúcia Portela Diniz ${ }^{4}$
}

\begin{abstract}
Childhood malnutrition has been a major, long-standing health concern in northeastern Brazil. In response, during 1992-1994, the state government of Ceará, with financial support from the World Bank, established 34 new nutrition centers. During 1996 an evaluation of the centers was conducted to determine their effectiveness in treating children with malnutrition and to identify weaknesses in the system and possible solutions. Also evaluated were the adequacy of resources, admission and discharge criteria, staff training, and community satisfaction. Effectiveness was found to be low. Treatment procedures did not conform with World Health Organization recommendations. Rates of weight gain were inadequate, and the mean duration of rehabilitation-8.7 months - was too long. Case fatality in two centers was unacceptably high, $40 \%$ and more. Entry and exit criteria for rehabilitation were ill defined, resulting in some nonmalnourished children being enrolled. Few staff were adequately trained; knowledge was weak, especially about case management; and mothers were not effectively instructed. Recommendations include setting objectives for the centers, improving referral systems, standardizing entry criteria, improving case management, and establishing performance indicators.
\end{abstract}

Childhood malnutrition is a major health concern in northeastern Brazil, including in the state of Ceará (population 6.4 million). The prevalence of breast-feeding is low, with a mean duration of 4 months, according to a report of the Ceará State Secretariat of Health (1). That report and other studies (2) have indicated many additional concerns with childhood malnutrition. Complementary foods are introduced

\footnotetext{
1 Federal University of Ceará, Clinical Research Unit, Fortaleza, Ceará, Brazil.

2 London School of Hygiene and Tropical Medicine, Centre for Human Nutrition. Mailing address for correspondence: Centre for Human Nutrition, London School of Hygiene and Tropical Medicine, Keppel Street, London WC1E 7HT, United Kingdom. E-mail: a.hill@lshtm.ac.uk

3 State University of Ceará, Department of Nutrition Sciences, Fortaleza, Ceará, Brazil.

4 Ceará State Secretariat of Health, Viva Criança Program, Fortaleza, Ceará, Brazil.
}

early, often from the first month, and are usually of low energy and nutrient density, monotonous, and prepared under unhygienic conditions. Infections and inadequate dietary intakes result in stunted growth. Wasting (low weight-for-height) is also seen, particularly during times of economic hardship and drought. There is a high infant mortality rate (68 per thousand live births in 1990), and widespread malnutrition has occurred, such as during the 1992-1993 drought.

In response to those conditions, the Ceará state government, with support from UNICEF, motivated communities and their leaders to enter into an Agreement for Child Nutrition with their municipalities. As part of this initiative, a network of nutrition centers was planned to provide both preventive and curative activities, primarily focus- ing on community education and mobilization and on treating moderately and severely malnourished children who had no medical complications.

The nutrition centers were seen as an integral part of the health system in Ceará, which is decentralized and has a tiered structure. There are 184 municipalities, and for $80 \%$ of the population the first points of contact with the health system are the 9000 community health workers (CHWs). In 64 municipalities the next level of assistance is the Family Health Program, which includes a doctor and a nurse. They supervise the CHWs, and the program is gradually expanding. In the other municipalities, CHWs are attached to health centers where primary health care is provided. Patients needing referral attend hospitals in the municipalities or in Fortaleza, the state capital. 
During 1992-1994, the state government, with financial support from the World Bank, established 34 nutrition centers. The centers are part of the Viva Criança program, which is under the direction of the state health secretariat. Each center is expected to have a coordinator, a nutritionist, and support staff. Doctors and nurses are not part of the permanent staff. The centers were modeled on the state's only preexisting nutrition center, in Conjunto Palmeiras, a slum area of Fortaleza. The successes of that small urban center led to the state health secretariat's decision to establish centers throughout the state. Due to decentralization, municipalities have a degree of autonomy and flexibility in relation to activities within their nutrition centers. Nevertheless, all centers are expected to observe the objectives as originally planned. Figure 1 sets out these objectives in terms of program inputs, intermediate outputs, and to: 1$)$ provide nutrition training for center staff and community health workers, 2) identify, treat, and then follow outcomes. The four main elements are

up moderately and severely malnourished children, 3) provide up-to-date nutrition information to mothers and others in the community, and 4) mobilize the community to find and implement strategies to prevent child malnutrition. In 1996, the nutrition centers were evaluated to determine whether they were treating malnourished children effectively. Also analyzed were the adequacy of resources, admission and discharge criteria, staff training, and community satisfaction. The aim was to identify weaknesses in the system and suggest possible solutions.

\section{MATERIALS AND METHODS}

The 34 new centers and the original center in Conjunto Palmeiras were each visited for 3-5 days between January and April 1996. During the visits, information was collected, including integration into community health services, objectives as seen by the center staff, activities, available human and physical resources, case-manage-

FIGURE 1. Framework and causal pathway linking program inputs with expected outcomes

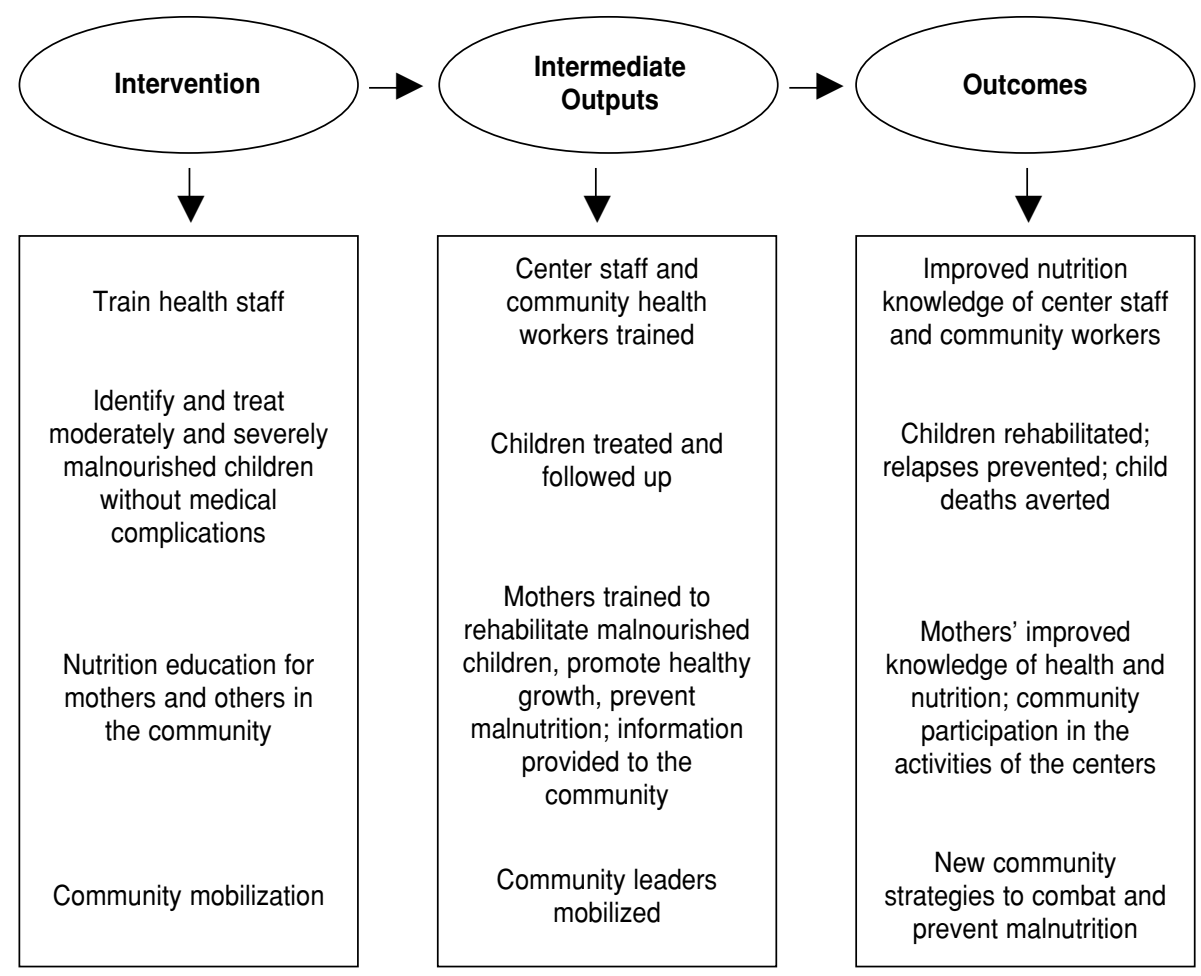

ment procedures, and affiliations such as with the state or municipal government. To determine utilization of the services and the profile of children attending, data were collected on caseload, entry and exit criteria for rehabilitation, child age, severity of malnutrition, and socioeconomic indicators. To quantify the effectiveness of treatment, information was obtained on mortality, rate of weight gain, length of stay, relapse rate, and community follow-up.

As a further measure of performance, case-management procedures in each center were examined to determine whether they conformed with World Health Organization (WHO) guidelines (3). Ten key indicators of "good practice" were selected. These included whether the center divided treatment into two phases (an initial stabilization phase and a longer rehabilitation phase); set specific nutritional goals for each of these two phases and then achieved them; provided night feeds and additional potassium, magnesium, zinc, and copper for at least two weeks; withheld iron in the initial phase; provided the children psychosocial stimulation during treatment; and oriented mothers about improved child feeding and health.

In centers that had been functioning for at least 12 months, an assessment was made of the knowledge on child nutrition of both mothers participating in the centers' activities $(n=340)$ and ones not participating in the centers' activities $(n=294)$, community health workers $(n=106)$, and center staff ( $n=$ 66). Their level of satisfaction with the centers was also obtained, as was that of 107 community leaders. Data were collected by 15 interviewers under the supervision of the main investigator and two nutritionists from the Viva Criança program. The interviewers used structured precoded forms.

After the data were cleaned and checked for internal validity and consistency, statistical analyses were conducted with the Statistical Package for the Social Sciences/PC+ version 5.0.1 (SPSS Inc, Chicago, Illinois). Descriptive statistics were used for frequencies, to calculate the main outcomes 
(length of stay, rates of weight gain, mortality), and to compare treatment procedures with the norms for "good practice." Single additive knowledge scores were created, and differences in scores between mothers participating in nutrition center activities and those not participating were tested by the $t$ test for independent samples. Oneway analysis of variance (ANOVA) was used to compare the level of knowledge of mothers, community health workers, and center staff.

After completion of the data analysis, a workshop was convened to disseminate the findings to health planners, nutrition and health professionals, and others. The objective was to formulate an action plan, including operational and training actions.

\section{RESULTS}

\section{Center plans and actual functioning}

Of the 35 centers, only 20 were functioning as nutrition centers. Nine centers had never opened, and six had been redirected to serve as health centers with no nutrition activities. Data analysis is thus confined to the 20 functioning centers.

All nutrition centers were expected to provide nutrition rehabilitation and psychosocial stimulation for malnourished children, education for mothers and other caretakers, and community mobilization. Figure 2 shows the actual activities the evaluation found. Whereas all the centers provided curative care, there was less attention given to preventive measures. No center was involved in community mobilization. In contrast, some activities were frequently undertaken that were not planned. These included family planning and distribution of food to children and pregnant women. Three centers provided outpatient treatment only (food distribution), 6 provided day care only (6-10 hours of care, with meals, five days per week), and 11 provided both outpatient and day-care services.

In addition to documenting the services actually provided, center coordinators were asked how they perceived
FIGURE 2. Activities in the 20 nutrition centers in Ceará, Brazil, 1996 (\% of centers)

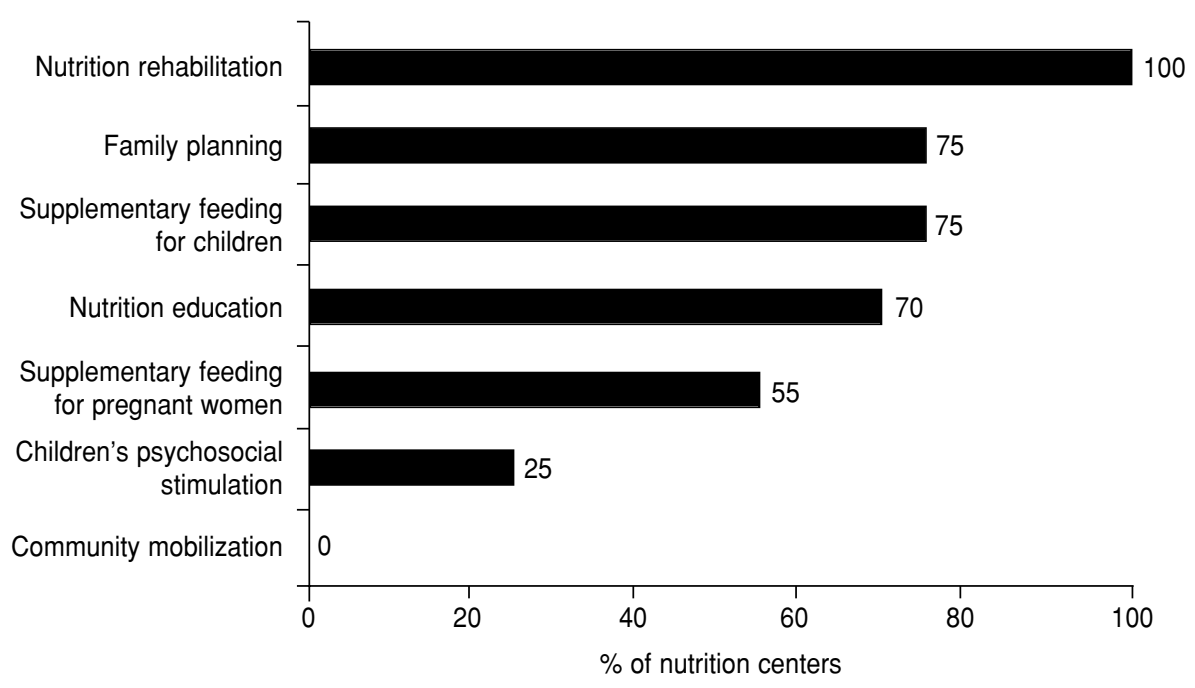

the centers' role. While all considered curative care the primary role, $70 \%$ also mentioned nutrition education, and $65 \%$ also included malnutrition prevention.

\section{Center resources}

Most of the centers were built as designed and were pleasant places. However, to function effectively, resources needed to be in place. These included human resources, weighing and measuring equipment to assess the severity of malnutrition and monitor the response to treatment, and ingredients to feed the children adequately and to correct deficiencies of potassium, magnesium, zinc, copper, iron, and vitamins. For preparation of feeds, blenders and a refrigerator would have been useful. Figure 3 shows the percentage of centers that had these resources. Overall, trained personnel were lacking. Only seven centers had a nutritionist, and only $57 \%$ of the 139 people working directly with children were trained. Seven coordinators were untrained. The training curriculum was not clearly defined and not necessarily updated to reflect advances in knowledge.

Length boards existed in most centers but were used in only six due to lack of training. Four centers lacked scales for weighing the children. Even though all the centers had the ingredients to prepare suitable rehabilitation diets, the nutrition content was unknown in $95 \%$ of the centers. Antibiotics, iron, and vitamins were available, but not potassium, magnesium, zinc, or copper.

\section{Users of the centers}

Caseloads were low. Of the centers, $60 \%$ assisted fewer than 50 children per month. Only three centers assisted more than 100 per month. The records of all children attending in the previous 12 months were reviewed ( $n=$ 1399). It is notable that there was no systematic recording even though the record forms were specially designed for routine use and contained information essential for monitoring case management. Recording was slightly better in the two training centers in Fortaleza (Conjunto Palmeiras and the Albert Sabin Children's Hospital). There was no administrative system to monitor and evaluate the centers.

Of the children attending, 53\% were under 18 months of age. There were equal numbers of boys and girls. Breast-feeding rates were low, with $50 \%$ breast-fed for less than 3 months 
FIGURE 3. Resources present in the 20 nutrition centers in Ceará, Brazil, 1996 (\% of centers)

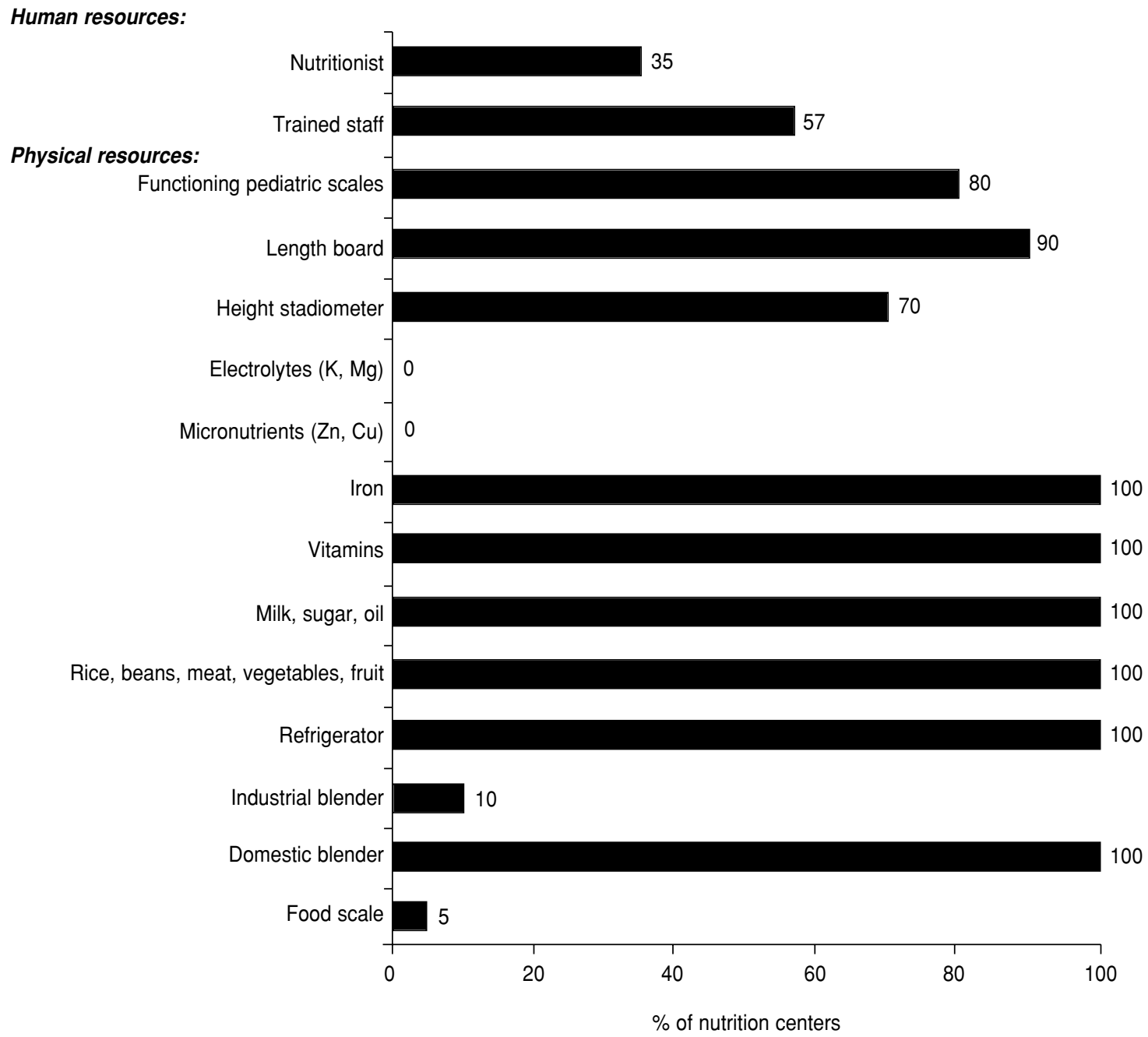

and $13 \%$ never breast-fed. Low-birthweight infants comprised $20 \%$ of the total at the centers, compared with an $8 \%$ overall prevalence in Ceará.

\section{Enrolled children and malnourishment}

All the centers used admission and discharge criteria, but they were ill defined and not standardized. Nine different criteria were documented. These included Gomez grade II, Gomez grade III, 10th centile weightfor-age, 90\% weight-for-height, direction of the growth curve, direction in the last two or more months, clinical signs, and social situation (4). Several criteria were often used simultaneously within the same center, and in some, criteria differed for outpatient and daycare children. For $37 \%$ of children, nutritional status was not recorded. The Gomez classification was commonly used at admission and was recorded for 898 of the 1399 children. Few (14\%) were severely malnourished (grade III), the largest group were moderately malnourished $(47 \%)$, and $40 \%$ were mild or normal cases. The Gomez classification is based on weight-for-age, which does not distinguish children who are wasted (low weight-forheight) from those who are stunted (low height-for-age). The proportion of wasted children attending the centers is shown in Table 1 . Few $(11 \%)$ were se- verely wasted; most $(62 \%)$ were mild or normal and should not have been admitted. Although weight-for-height or weight-for-length is the recommended indicator for admission and discharge, and although $90 \%$ of centers were equipped to measure length, only one-third of the children were classified in this way.

\section{Rate of exit and degree of effectiveness}

Rehabilitation of even extremely severe cases should not take more than eight weeks. When reviewing 12 months' records, one would therefore expect that at least $85 \%$ of children 
TABLE 1. Frequency distribution of weightfor-height of children admitted during a 12month period to nutrition centers in Ceará, Brazil (1995-1996)

\begin{tabular}{lrr}
\hline & \multicolumn{2}{c}{ Frequency } \\
\cline { 2 - 3 } \% weight-for-height $^{\mathrm{a}}$ & \multicolumn{1}{c}{$n$} & \multicolumn{1}{c}{$(\%)$} \\
\hline$>90$ & 23 & $(5.2)$ \\
$81-90$ & 251 & $(57.1)$ \\
$70-80$ & 119 & $(27.0)$ \\
$<70$ (severely wasted) $^{\text {n }}$ & 47 & $(10.7)$ \\
Total $^{\text {b }}$ & 440 & $(100.0)$
\end{tabular}

${ }^{a}$ Compared with median value of reference population from U.S. National Center for Health Statistics (NCHS).

${ }^{b}$ Height information missing on 909 children.

would be discharged. This was true of only $7 \%$ of the children (Table 2 ). Most centers had low mortality (see below), but very high mortalities in two centers resulted in a high average value (14\%). Of those who died, 91\% were being treated as outpatients. Abandonment of treatment was common $(17 \%)$, and of these, $66 \%$ were day-care children.

In the management of malnutrition, the $\mathrm{WHO}$ recommends the use of two performance indicators, case-fatality rates and rates of weight gain (3). Two of the Ceará centers accounted for $70 \%$ of the deaths among the children, having case-fatality rates of $40 \%$ and $50 \%$, respectively. The remainder had acceptable rates, under $5 \%$.

Weight gains of less than 5 grams per kilogram of body weight per day are poor, according to the WHO (3). Rates of weight gain were calculated for $227(71 \%)$ of the Ceará children receiving day care in the centers that had been functioning for 12 or more months (Table 3). Poor weight gain was observed in $95 \%$ of these cases. Indeed, the large majority (79\%) gained less than $2 \mathrm{~g} / \mathrm{kg} /$ day. Consequently, few children were discharged. The few who were discharged had a mean length of stay of 8.7 months.

\section{Treatment procedures and good practice}

The percentage of centers in which treatment conformed with WHO
TABLE 2. Completion rates among children admitted during a 12-month period to nutrition centers in Ceará, Brazil (1995-1996)

\begin{tabular}{lrr}
\hline \multirow{2}{*}{\multicolumn{1}{c}{ Status }} & \multicolumn{2}{c}{ Frequency } \\
\cline { 2 - 3 } & $n$ & \multicolumn{1}{c}{$(\%)$} \\
\hline Treatment still ongoing & 637 & $(61.2)$ \\
Dropped out & 173 & $(16.6)$ \\
Died & 144 & $(13.8)$ \\
Discharged & 75 & $(7.2)$ \\
Moved out $_{\text {Total }}{ }^{\mathrm{a}}$ & 11 & $(1.0)$ \\
& 1041 & $(100.0)$ \\
\hline
\end{tabular}

a Information missing on 358 children.

guidelines (3) is shown in Figure 4. None of the centers reported having a stabilization phase and a catch-up growth phase for the children. Few centers $(25 \%)$ had nutritional goals. None of them assessed dietary intakes, so they did not know if they achieved their nutritional goals. The centers used milk, porridges, and soups interchangeably but without knowing their nutritional content. The centers did not give micronutrients (zinc and copper) or electrolytes (potassium and magnesium). If available, a nutritionist and/or pediatrician examined the children daily. The centers gave antibiotics only if there was a diagnosed infection. The inadequate treatment procedures reflect the poor knowledge of center staff about child nutrition (see below).

\section{Staff and mothers' knowledge of child nutrition and health}

A knowledge questionnaire with the same 50 questions on child nutrition and health was used for center staff, CHWs, and mothers. In addition to the total score, three subscores were compiled, on infant feeding, nutrition and infection, and nutrition rehabilitation. An additional questionnaire was given to center staff and CHWs to check specific knowledge pertaining to assessment, treatment, and prevention of malnutrition. Both questionnaires were pretested and validated before being used.

Table 4 shows the total scores (maximum attainable $=30$ ). There was no
TABLE 3. Mean weight gain among daycare children admitted to nutrition centers during a 12-month period in Ceará, Brazil (1995-1996)

\begin{tabular}{lrr}
\hline \multirow{2}{*}{$\begin{array}{l}\text { Mean weight gain } \\
\text { (g/kg/day) }\end{array}$} & \multicolumn{2}{c}{ Frequency } \\
\cline { 2 - 3 } & \multicolumn{1}{c}{$n$} & $(\%)$ \\
\hline Less than 2 & 180 & $(79.3)$ \\
$2-4$ & 36 & $(15.9)$ \\
$5-10$ & 10 & $(4.4)$ \\
$>10$ & 1 & $(0.4)$ \\
Total $^{\text {a }}$ & 227 & $(100.0)$ \\
\hline a Information missing on 92 children. & &
\end{tabular}

difference in scores between mothers who participated in the centers' activities and those who did not participate ( $t$-test $P=0.40)$, and their combined results are presented. Center staff and CHWs had significantly higher mean scores than mothers (ANOVA $P<$ 0.005). The subscores showed a similar pattern (data available on request). Knowledge about nutritional rehabilitation was particularly weak. Center staff had a mean of $28 \%$ correct answers, with the highest individual score being $50 \%$ correct.

\section{Perceptions of the centers' services}

Mothers and CHWs are, in different ways, users of the services provided by the nutrition centers, and community leaders can influence management and policy decisions. Their views about the centers, as well as those of the center staff, were therefore of interest.

Table 5 shows those four groups' opinions about the quality of the services and their usefulness to the community. Few mothers, CHWs, or center staff were dissatisfied, but $29 \%$ of community leaders considered the centers of poor quality, and $25 \%$ as not useful.

\section{DISCUSSION}

The survey revealed a low level of effectiveness in all the nutrition centers. Rates of weight gain were unacceptably slow. So were rates of recovery, with a mean duration of 8.7 months. 
FIGURE 4. Extent to which treatment conformed with good practice in the 20 nutrition centers in Ceará, Brazil, 1996 (\% of centers)

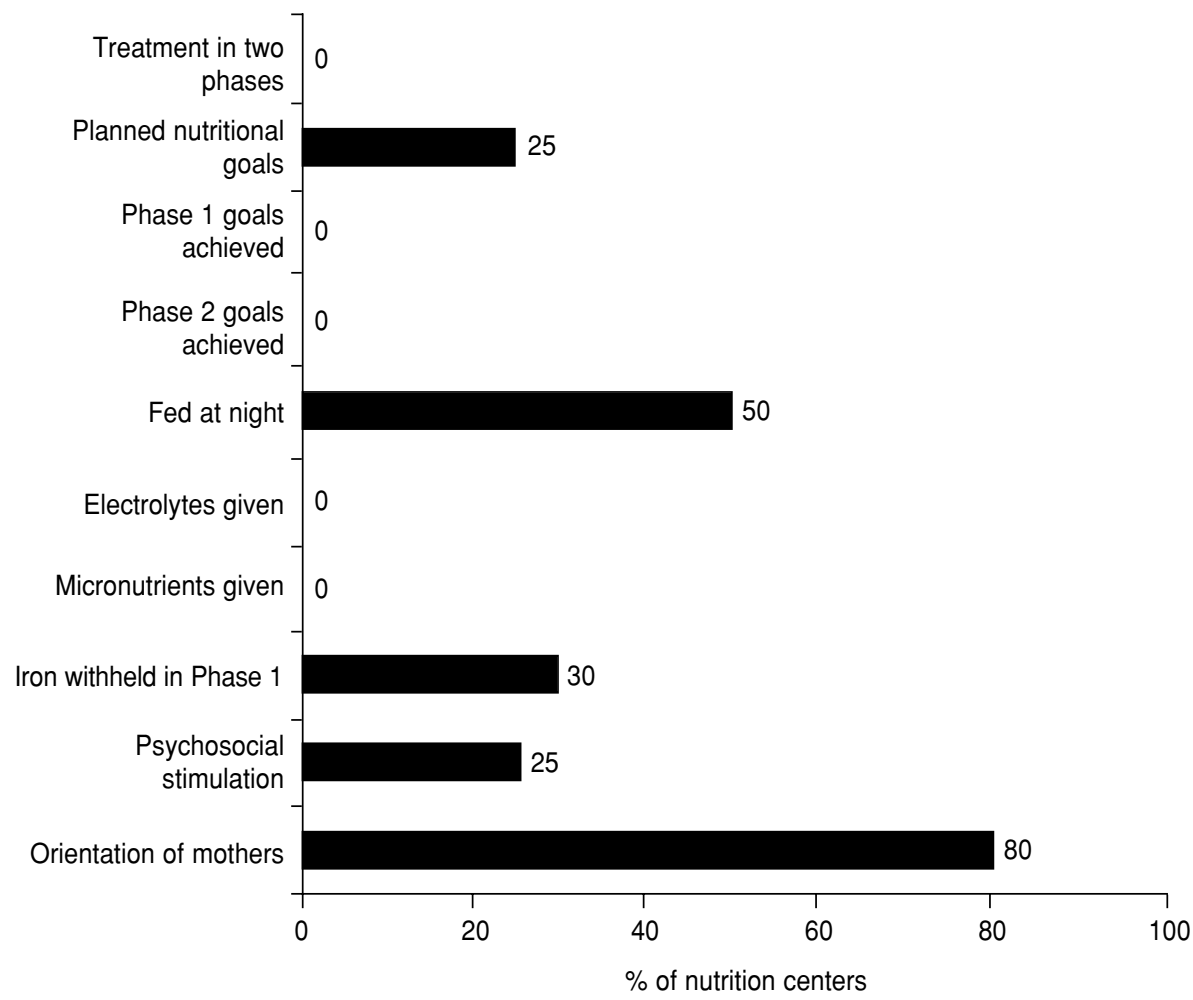

Mortality was unacceptably high in two centers, reaching $40-50 \%$. Abandonment of treatment among day-care patients was common since homes were often far from the centers and daily attendance for long periods placed impossible demands on mothers. Physical resources in the centers were relatively good, the main weaknesses being lack of potassium, magnesium, zinc, and copper, and no means of assessing nutritional intake.
There was an imbalance between curative and preventive care.

The centers were operationally weak, with an inadequate referral system resulting from the fact that the centers were not integrated into either the community health program or the family health program. This problem was linked to the centers being decentralized to the municipalities. Even the objectives were decentralized. Salaries were provided by the municipalities,

TABLE 4. Knowledge scores of nutrition center staff, community health workers, and mothers about child nutrition in Ceará, Brazil (1996)

\begin{tabular}{lcccr}
\hline & \multicolumn{3}{c}{ Score $^{\mathrm{a}}$} \\
\cline { 2 - 5 } Category & Mean & $(\mathrm{SD})$ & Minimum & Maximum \\
\hline Center staff & 17 & $(3)$ & 10 & 22 \\
CHWs & 17 & $(2)$ & 11 & 6 \\
Mothers & $13^{\mathrm{b}}$ & $(3)$ & 62 & 22 \\
\hline
\end{tabular}

a Maximum score attainable $=30$.

b Significantly different (ANOVA $P<0.005)$.

and therefore the state government had little political power to ensure good practices or to engender change. No nutritionists were employed in the family health program yet it had a role in executing and supervising activities to promote nutrition. There was a high turnover of CHWs and they were poorly supervised. Lacking doctors, the centers were not used spontaneously by parents and instead depended on referrals. The absence of any formal referral system and lack of community mobilization could explain the low utilization of the centers. Adding to this and dampening motivation for change was a prevailing attitude that malnutrition was inevitable.

Lack of trained staff was a major problem. Most centers were in rural areas and did not attract qualified workers. Appointments to the positions tended to be made on the basis of work experience and potential, rather than on professional qualification. This was reflected in inappropriate treatment procedures and the poor knowledge scores of staff. In-service training should therefore be a priority for existing staff and for any untrained workers appointed in the future. Although most centers had an education program for mothers, their knowledge scores were no different from those of nonparticipating mothers, indicating poor impact.

For the future we recommend:

- Defining a minimum set of objectives. This would ensure integration with other health programs and avoid duplication. Clear strategies need to be defined for each objective.

- Standardizing entry and discharge criteria for malnourished children. This standardization should emphasize weight-for-height (or weight-forlength in children under two years). This will help to avoid nonwasted children being admitted for recuperative care. Referral procedures need to be initiated. There are two broad categories of children who could usefully be referred to nutrition centers: a) severely malnourished children who have received initial treatment in a hospital and are ready for rehabilitation (Phase 
TABLE 5. Opinions on the quality of services and usefulness of the centers held by mothers, community health workers, center staff, and community leaders (\%) in Ceará, Brazil (1996)

\begin{tabular}{lcccc}
\hline \multicolumn{1}{c}{ Opinion } & $\begin{array}{c}\text { Mothers } \\
(n=634)\end{array}$ & $\begin{array}{c}\text { CHWs } \\
(n=106)\end{array}$ & $\begin{array}{c}\text { Center staff } \\
(n=66)\end{array}$ & $\begin{array}{c}\text { Community leaders } \\
(n=107)\end{array}$ \\
\hline $\begin{array}{l}\text { Quality of services: } \\
\text { Very good }\end{array}$ & 31.4 & 28.3 & 47.0 & \\
Good & 66.4 & 56.6 & 48.5 & 23.4 \\
Fair & 0.5 & 11.3 & 4.5 & 28.6 \\
Poor & 0.5 & 3.7 & 0 & 28.8 \\
Usefulness for the community: & & & & \\
Very useful & 39.3 & 28.3 & 43.9 & 56.1 \\
Useful & 60.0 & 67.0 & 51.5 & 18.7 \\
Not very useful & 0.6 & 4.7 & 4.5 & 25.2 \\
\hline
\end{tabular}

2) and b) moderately malnourished children (below -2SD weight-forheight) referred from the family health and community health programs, or other agencies. Mothers of children who are above -2 SD weightfor-height but stunted should receive nutrition education.

- Considering an alternative treatment strategy. That strategy could combine a preliminary week of day care at the center with weekly follow-up. In addition to treating the child, the aim is to teach the mother/caretaker how to rehabilitate the child effectively at home. This requires specific instructions about what to feed, how often, and how much (5).

- Implementing performance indicators. These indicators should place priority on case-fatality rates, percentage of admitted children who are successfully rehabilitated (i.e., attain -2SD weight-for-height), and weeks taken to achieve -2SD weight-for-height.

- Improving case management using the WHO treatment guidelines. These standards have been successfully implemented at the Institute for the Prevention of Malnutrition and Disability and at the Albert Sabin Children's Hospital in Fortaleza, where simple changes to routines have solved long-standing problems of continuing diarrhea, poor appetite, and poor growth (6). Training needs to be implemented for all center staff about topics related to child nutrition, psychosocial stimulation, and disease prevention. Local universities need to take a stronger role in training, in developing training materials, and in developing evaluation methodologies.

Acknowledgments. We thank the World Bank for its financial support, and the British Council and the School of Public Health, Ceará, for facilitating this work. Cristina Maria Gomes do Monte is supported by the Brazilian Research Council for Science and Technology. We thank the interviewers, supervisors, and all the respondents (more than 1000) who graciously gave their time in answering our many questions, and M.Z. Hollanda for statistical analysis.

\section{REFERENCES}

1. Secretaria Estadual de Saúde do Ceará. Saúde materno-infantil no Ceará: Resultados das PESMICs 1, 2 e 3. Fortaleza: SESA-Ce; 1995.

2. Monte CMG, Sá MLB, eds. Guias alimentares para as crianças de 6-23 meses no Nordeste do Brasil. Fortaleza: The British CouncilNordeste do Brasil; 1998.

3. World Health Organization. Management of severe malnutrition: A manual for physicians and other senior health workers. Geneva: WHO; 1998 (forthcoming).

4. World Health Organization. Physical status: The use and interpretation of anthropometry. Geneva: WHO; 1995.

5. Khanum S, Ashworth A, Huttly SRA. Controlled trial of three approaches to the treatment of severe malnutrition. Lancet 1994;344: 1728-1732.
6. Cavalcante AAM, Pinheiro LMP, Monte C, Guimaraes ARP, Ashworth A. Treatment of malnutrition in Brazil: Simple solutions to common problems. Trop Doctor 1998;28:95-97.

Manuscript received on 1 December 1997. Revised version accepted for publication on 17 August 1998. 
RESUMEN La malnutrición ha sido por largo tiempo un preocupante problema de salud en la región nordeste del Brasil. Para responder a esta situación, en el período de 1992 a 1994 el gobierno estatal de Ceará recibió apoyo del Banco Mundial para establecer 34 centros de nutrición. En 1996 se llevó a cabo una evaluación de los centros para precisar su efectividad en el tratamiento de niños malnutridos, los puntos débiles del sistema y posibles soluciones. También se evaluaron la suficiencia de los recursos, los criterios de admisión y alta, la capacitación de los empleados y la satisfacción de la comunidad. La efectividad resultó ser baja. Los procedimientos de tratamiento no correspondían a las recomendaciones de la Organización Mundial de la Salud. Las tasas de aumento de peso eran inadecuadas y la duración media del período de rehabilitación - 8,7 mesesdemasiado larga. La tasa de letalidad en dos centros era inadmisiblemente alta: $40 \%$ y más. Los criterios de admisión y alta estaban mal definidos, por lo que había niños no malnutridos bajo tratamiento. La mayor parte del personal carecía de capacitación adecuada y contaba con pocos conocimientos, especialmente sobre el manejo de casos; además, las madres no estaban recibiendo instrucción apropiada. En consecuencia, se recomendó fijar objetivos para los centros, estandarizar los criterios de admisión, mejorar el manejo de casos y establecer indicadores de resultados.

\section{Efectividad de los centros de nutrición del estado de Ceará, nordeste del Brasil}

\section{Sexta Conferencia Anual sobre Epidemiología y Prevención de las Enfermedades Infecciosas: enfermedades infecciosas emergentes}

Fechas: $\quad 11$ a 13 de febrero de 1998

Lugar: $\quad$ San Francisco, California

El programa de cursos de esta conferencia será presentado por el Departamento de Epidemiología y Bioestadística de la Escuela de Medicina, Universidad de California en San Francisco, con la cooperación de los Centros para el Control y la Prevención de Enfermedades, el Departamento de Servicios de Salud de California y el Departamento de Salud Pública de San Francisco. Está dirigido a practicantes de las disciplinas de epidemiología, salud pública, administración de la salud, medicina, enfermería y profesiones afines. Tal como está previsto, ofrecerá una visión general del alcance y los métodos empleados en la investigación y epidemiología de las enfermedades infecciosas; el problema de la resistencia microbiana a los medicamentos, y la epidemiología y la prevención de las enfermedades infecciosas importantes: VIH; coccidioidomicosis; enterococos, tuberculosis e infecciones por Salmonella resistentes a los medicamentos; hepatitis C; virus del papiloma humano; cáncer cervicouterino; citomegalovirus, y enfermedades de transmisión sexual. Los participantes pueden obtener acreditación de 14,5 horas en medicina o enfermería continua.

Información:

Lynda McNeal, Office of Continuing Medical Education

UCSF Box 0742

San Francisco, California 94143-0742

Teléfono: (415) 476-4251; fax: (415) 476-0318 